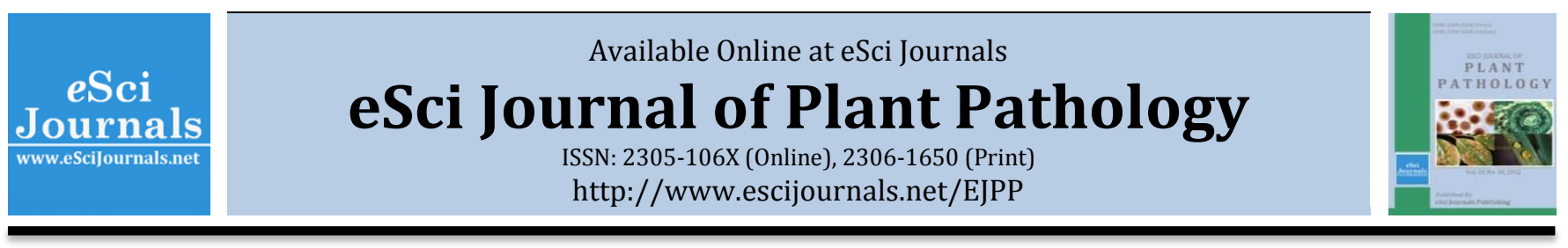

\title{
INCIDENCE OF POTATO VIRUSES IN DIFFERENT DISTRICTS OF KHYBER PAKHTUNKHAWA, PAKISTAN
}

\author{
aZishan Gul, bAftab A. Khan, aAsif U. R. Khan, aZaheer U. Khan \\ ${ }^{a}$ Hazara Agriculture Research Station, Abbottabad, Pakistan. \\ b Department Of Botany, Government Post Graduate College, Abbottabad, Pakistan.
}

\section{A B S T R A C T}

Three consecutive potato crops are grown annually in Pakistan and Khyber Pakhtunkhawa (KPK) province is the main source for seed tubers. During the year 2010, 240 symptomatic and viral susceptible potato leave samples were collected from Swat, Dir, Abbottabad and Mansehra and serologically confirmed through Double Antibody Sandwich (DAS) Enzyme Linked Immunosorbant Assay (ELISA) against Potato virus X (PVX), Potato virus Y (PVY), Potato leaf roll virus (PLRV), Potato virus M (PVM), Potato virus S (PVS) and Potato virus A (PVA). The presence or absence of viruses was confirmed by observing the yellow and white color in ELISA plates respectively. According to ELISA results, overall percentage incidence of viral diseases was found highest in Swat (65\%) followed by Mansehra (61\%), Dir (53\%) and Abbottabad (43.33\%) while PVY and PVS were dominant in Swat (26.66\%), Dir (20\%), Mansehra (15\%) and Abbottabad (21.66\%) respectively. PVX was not detected in Abbottabad while Swat samples seemed to be free from PVM and PVA.

Keywords: Potato viruses; Pakistan; Incidence; Field survey.

\section{INTRODUCTION}

The edible potato (Solanum tuberosum L) is the world's leading vegetable and staple food crop and ranked fourth in production after rice, wheat and maize (Rauscher et al., 2006). Potato crop provides 15 times more production per hectare and calories per unit area is also higher than other cereals (wheat, maize and rice) while vitamins, proteins and carbohydrates also achieved from potato tubers (MacGillivary, 1953). In Pakistan, potato crop covers 159.4 thousand hectares and provides 3491.7 thousand tons production which plays a vital role in the Gross Domestic Product (GDP) of the country but the production of potato crop is still less as compared to the other potato growing countries (GOP 2011).

Bacteria, nematode, fungus (Khalid et al., 2000) and virus (Abbas et al., 2012) along with abiotic factors play a vital role for yield reduction in potato crop of Pakistan. A significantly high number of pathogens and pests can be transferred from one place to another through seed propagation and among them, PVX, PVY,

* Corresponding Author:

Email: gul.zishan@gmail.com

(C) 2012 eSci Journals Publishing. All rights reserved.
PVS, PLRV, PVA and PVM are most significant in Pakistan. Potato growers introduced high yielding foreign potato varieties in Pakistan which enhanced the yield of potato crop but at the same time new viral diseases are also reported in spring, summer and autumn potato crops which cause up to $83 \%$ yield losses (Abbas et al., 2012; Mughal and Khalid, 1985) and most viruses can effectively be determined by ELISA tests (Petrrunk et al., 1991). Muhammad (1990) surveyed Pabbi, Bunair and Swabi areas of KPK and reported the mean incidence of PLRV, PVY, PVS and PVA as $4.29 \%, 5.97 \%, 13.26 \%$ and $0.47 \%$, respectively. Ahmad and Ahmad, 1995 reported that the seed borne viruses are spreading in potato growing areas of Pakistan through the seed tubers.

Chaudhri et al., 1992 observed that market seed tubers were heavily infected with viral diseases, on average $48 \%$ during autumn and $52 \%$ in spring season crops and mainly by PVY. Giving the losses incurred due to these viruses, the present research work was aimed to determine the prevalence of potato viruses in major potato growing districts of Khyber Pakhtunkhawa (KPK) province of Pakistan i.e. Swat, Dir Abbottabad and Mansehra. 


\section{MATERIALS AND MEHTODS}

Field surveys and sample collection: During the Year 2010-11, survey of potato field in Swat, Dir, Abbottabad and Mansehra was conducted and a total of 240 samples of 7-10 weeks old field growing potato plants were collected on the basis of viral like visual symptoms (Stunting, vein clearing, mosaic, mottling, leaf rolling, and vein-banding) (Fig. 1) following the ' $\mathrm{Z}$ '
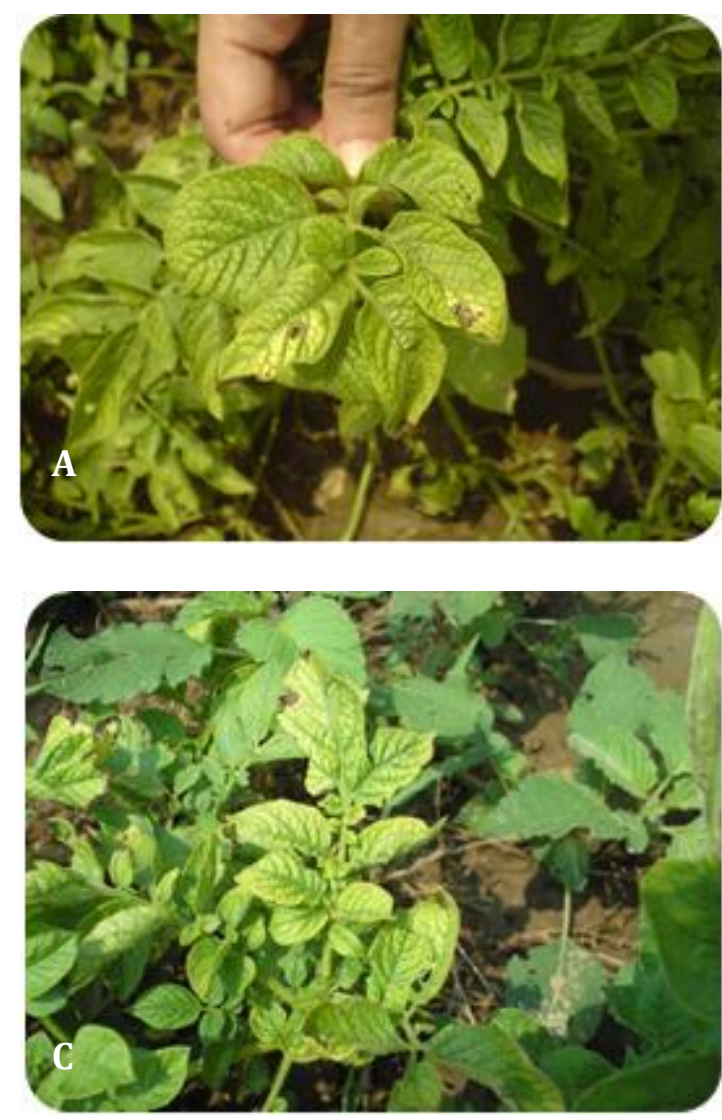

pattern as a sampling procedure (Zehnder, 2010). A single sample consisted of three single leaves plucked from top, middle and bottom of potato plant and placed in appropriate labeled polythene zipper bags to indicate location, sample number and date of collection. These samples were brought to virology lab at Federal Seed Certification and Registration Department, Islamabad and stored at $4^{\circ} \mathrm{C}$ until testing.
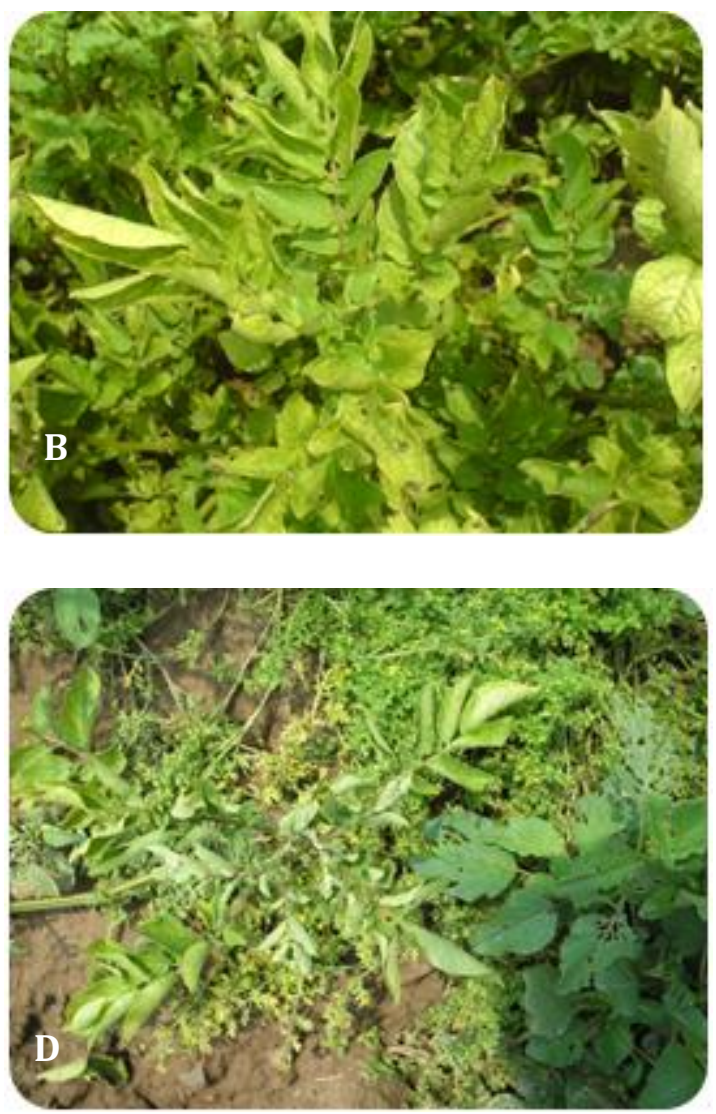

Figure1: Potato plants showing symptoms of mosaic, mottling, yellowing $(A, C)$ and leaf rolling $(B, D)$ at the time of sample collection from different districts.

Serological detection: All suspected potato samples were tested against PVX, PVY, PVA, PVM, PVS and PLRV through DAS-ELISA as described by Clark and Adams (1977) using antibodies (BIOREBA kit). Monoclonal antibodies (IgG) were diluted in coating buffer $(1 \mu \mathrm{l}: 500 \mu \mathrm{l})$ and ELISA plates were coated with diluted monoclonal antibodies $(100 \mu \mathrm{l} /$ well) for the six viruses PVX, PVY, PLRV, PVA, PVM and PVS. The coated plates were covered tightly and incubated for $3 \mathrm{~h}$ at room temperature. Potato leaves were grounded using pestle and mortar in extraction buffer and sap was filtered through muslin cloth while each well of plate was coated with $100 \mu$ l antigen (extracted sap) along with buffer and healthy control. The antigen coated plates were incubated over night at $4^{\circ} \mathrm{C}$ while enzyme alkaline phosphatase (ALKP) conjugated IgG were diluted (1:500) in conjugate buffer and added in each well. After each step, three washing at 3 min interval was performed with washing buffer and plates were dried at paper towel. Then, substrate buffer $(150 \mu \mathrm{l})$ containing p-nitro phenyl phosphate $(1 \mathrm{mg} / \mathrm{ml})$ was added to each well and plates were incubated in dark for 01 hour while the color reaction was observed visually and also read on ELISA reader at $405 \mathrm{~nm}$. A sample is considered as virus infected when the absorbance of $405 \mathrm{~nm}$ was at least thrice of that of the healthy control. Incidence of potato viruses was calculated by following formula:

$$
\% \text { Incidence }=\frac{\text { No. of infected samples }}{\text { Total no of samples }} \times 100
$$




\section{RESULTS AND DISCUSSION}

Stunting, systemic vein clearing, mosaic, mottling, curling, shortening of leaves, dark green and veinbanding were observed on the potato while few plants exhibiting the leaf roll symptoms, entire leaflets were rolled while in others plants, it was only restricted to the leaflet bases (Fig 1). Symptomlogy is not a reliable tool for detection of virus diseases in the potato crop because symptom development is due to many factors such as insect sucking, environmental conditions, nutrition deficiency, growth stage, host genotype and virus strain but it can play a vital role in disease diagnosis (Batool et al., 2011). The symptomatic potato plants were further confirmed serologically through ELISA and according to ELISA results, highest percentage incidence of viral infection was found in Swat, followed by Mansehra, Dir and Abbottabad (Table 1).Potato virus $X$ is among the top ten most economically damaging plant viruses in the world and cause significant yield losses in potato crop (Abbas and Hameed 2012). The symptoms of plants infected with PVX showed mild leaf mosaic pattern, crinkling, thickening and wrinkled leaves and the infected sap reacted strongly with all infected plants by the DASELISA test (Fig 2). Maximum and minimum incidence of PVX was observed in Mansehra (10\%) and swat (1.66\%) while samples from Abbottabad did not react against PVX. Potato plants exhibiting leaf mottling, mosaic and necrosis produced strong reaction against PVY and no district was found free from PVY infection. PVY is a nonpersistent virus and several aphid species transmit PVY after short probing that contribute to its prevalence. It can also be spread mechanically by human activity and secondary (tuber-borne) infections are the most significant component of PVY epidemiology as reported by Khurana and Garg, 1998) which are the main reasons of its prevalence. According to ELISA results, PVY was most predominant in all location. The increasing incidence of PVY is getting an alarming position in main potato growing areas of Pakistan (Abbas et al., 2012). Ahmad et al. (2003) also detected PVY at different percentage and similar results were also reported by different scientists (Jan and Khan, 1995; Mughal et al., 1986).
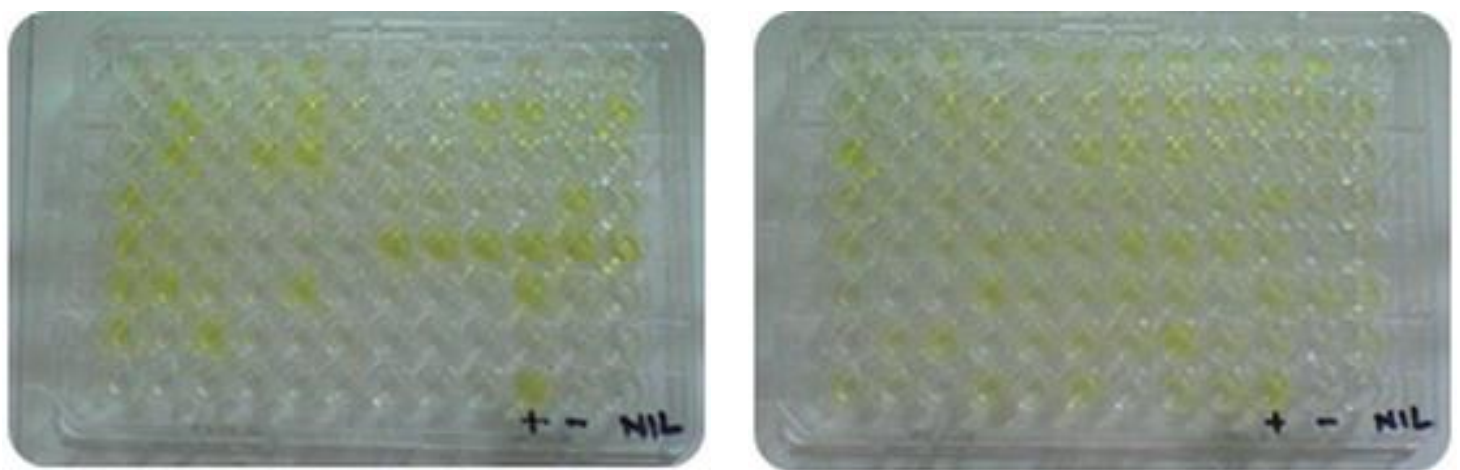

Fig2: Yellow color in ELISA plates indicates the presence of viruses in potato crop

Potato samples showing paleness and upward rolling of young leaves, stunted growth and yellowing of leaf margins were detected serologically against PLRV (Fig1) and Rodriguez and Jones (1978) also observed similar responses from field grown potato plants. PLRV lack the property of mechanical transmission but it was found in all districts with different percentage incidence (Table 1). It might be due to presence of alternate host, climatic conditions and vector activity, as the sampling was done in summer season. This may be one of the major factors that may account for high infection level of PLRV.

Table 1: Disease percentage incidence of potato viruses in different districts of Khyber Pakhtunkhawa (KPK) province.

\begin{tabular}{cccccccccc}
\hline Districts & $\begin{array}{c}\text { No. of } \\
\text { tested } \\
\text { samples }\end{array}$ & $\begin{array}{c}\text { No. of +ve } \\
\text { samples }\end{array}$ & $\begin{array}{c}\text { \% disease } \\
\text { incidence }\end{array}$ & & \multicolumn{1}{c}{ \% incidence of viruses detected } & \\
\hline & & & & PVX & PVY & PLRV & PVA & PVM & PVS \\
Swat & 60 & 39 & 65 & 3.33 & 26.66 & 8.33 & -- & -- & 26.66 \\
Dir & 60 & 32 & 53.33 & 1.66 & 8.33 & 8.33 & 1.66 & 6.66 & 20 \\
Abbottabad & 60 & 26 & 43.33 & -- & 8.33 & 13.33 & 5 & 5 & 15 \\
Mansehra & 60 & 37 & 61.66 & 10 & 3.33 & 16.66 & 6.66 & 3.33 & 21.66 \\
\hline
\end{tabular}


Khalid et al. (2000) observed mild mosaic patterns, crinkling and serious necrosis of leaves in PVM infected plants and same symptoms were observed form Dir, Abbottabad and Mansehra while no reaction of PVM was observed in any Swat area. PVS was also most predominant virus along with PVY in all locations (Table 2). Present survey revealed that PVS infection prevailed in all the four districts with highest incidence (Table 1). PVS is mainly transmitted by mechanical contamination as reported by Franc and Banttari, 2001 resulting in its spread during farming operations which might account for its relatively higher incidence. Moreover, large number of weeds were found in and around potato fields providing virus reservoirs for vectors serving as source of primary inoculum.

Tolerant or resistant potato varieties against viruses, treatment with chemotherapy and thermotherapy, meristem culture, insect pests along with weeds control may play a vital role in reducing yield losses in potato crop of Pakistan. Molecular identification of these viruses will also be helpful in understanding these viruses and thus improve the farmer's income.

Table 2: Incidence of six viruses in different location of Dir, Abbottabad, Swat and Mansehra distract.

\begin{tabular}{cccccccccc}
\hline \multirow{2}{*}{ Districts } & Locations & $\begin{array}{c}\text { No. of } \\
\text { tested } \\
\text { samples }\end{array}$ & $\begin{array}{c}\text { No. of } \\
+ \text { +ve } \\
\text { samples }\end{array}$ & \multicolumn{7}{c}{ \% incidence of viruses detected } \\
\hline \multirow{3}{*}{ Mansehra } & - & - & - & PVX & PVY & PLRV & PVA & PVM & PVS \\
& Bajna & 15 & 11 & 20 & -- & 26.6 & -- & -- & 26.6 \\
& Kaghan & 15 & 12 & 20 & 13.33 & 13.33 & -- & -- & 33.33 \\
& Shergarh & 15 & 8 & -- & -- & 6.66 & 13.33 & 13.33 & 20 \\
& Paras & 15 & 6 & -- & -- & 20 & 13.33 & -- & 6.66 \\
\hline Abbottabad & Nawashaher & 15 & 10 & -- & 6.66 & 26.6 & 13.33 & -- & 20 \\
& Bagnotar & 15 & 8 & -- & 6.66 & 13.33 & 6.66 & 6.66 & 20 \\
& Kalanderabad & 15 & 6 & -- & 6.66 & 13.33 & -- & 6.66 & 13.33 \\
& Nathiagali & 15 & 2 & -- & 13.33 & -- & -- & 6.66 & 6.66 \\
\hline Dir & MaidanValley & 15 & 2 & -- & -- & -- & -- & -- & 13.33 \\
& Usheri valley & 15 & 14 & -- & 26.6 & 13.33 & 6.66 & 6.66 & 40 \\
& Sherbangal & 15 & 7 & -- & 6.66 & 6.66 & -- & 20 & 13.33 \\
& Tal & 15 & 9 & 6.66 & -- & 13.33 & -- & -- & 13.33 \\
\hline \multirow{2}{*}{ Swat } & Tendo Dog & 15 & 10 & -- & 13.33 & 20 & -- & -- & 33.33 \\
& MalamJaba & 15 & 8 & -- & 40 & -- & -- & -- & 13.33 \\
& MaindamValley & 15 & 9 & -- & 26.66 & 13.33 & -- & -- & 20 \\
& Kalam & 15 & 12 & 13.33 & 26.6 & -- & -- & -- & 6 \\
\hline
\end{tabular}

\section{CONCLUSIONS AND RECOMMENDATIONS}

There is need to locate resistance against potato viruses in local potato cultivars that will improve our potato crop against these viruses in environmentally friendly manner to minimize the yield losses and to avoid the use of hazardous pesticides. In order to prevent the further spread of potato diseases and to avoid the introduction of new pathogens, it is advisable to reinforce the seed certification schemes that mandate using and trading with only certified potato seeds.

\section{REFERENCES}

Abbas, M.F, S. Hameed, A. Rauf, Q. Nosheen, A. Ghani, A. Qadir and S. Zakia. 2012. Incidence of six viruses in potato growing areas of Pakistan. Pak. J. Phytopathol. 24: 44-47.
Abbas, M.F. and S. Hameed. 2012. Identification of disease free potato germplasm against potato viruses and PCR amplification of potato virus X. INT. J. BIOL. BIOTECH. 9 (4): 335-339.

Ahmad, M. and W. Ahmad. 1995. Detection of major potato viruses from different potato growing localities of Punjab. Nat. Sem. Res. And Dev. Potato Prod. In Pak., PDP/PARC, Islamabad, Pakistan.

Ahmad, W., D. Iman and H.U. Jan. 2003. Recent trend of potato virus prevailing in potato growing areas of Punjab. Pak. J. Phytopathol. 15: 21-24.

Batool, A., M.A. Khan, J. Farooq, S.M. Mughal and Y. Iftikhar. 2011. ELISA-based screening of potato germplasm against potato leaf roll virus. J. Agric. Res. 49:57-63. 
Chaudhri, J.A., S.M.A. Shah and A. Hussain. 1992. Performance of seed potatoes production in high and mild hills of Kaghan in Pakistan. Sarhad J. Agric. 18: 87-94.

Clark, M.F. and A.N. Adams. 1977. Characteristics of the microplate method of enzyme-linked immunosorbent assay for the detection of plant viruses. Journal of General Virology. 34: 475-483.

Franc, G., E. Banttari. 2001. Mechanically transmissible viruses of potato. In: Loebenstein G, Berger P, Brunt A, Lawson R (Eds) virus and virus like diseases of potatoes, production of seed potatoes, Kluwer Academic Publishers, The Netherlands. 159-175.

GOP. 2011. Agricultural statistics of Pakistan. 2010-11. Government of Pakistan, Ministry of Food, Agriculture and Livestock, (economic Wing, Islamabad. 82-83.

Jan, H. and S.B. Khan. 1995. Incidence and distribution of potato viruses in the upper Kaghan Valley of Pakistan. Pakistan J. Phytopathol. 7: 13-6.

Khalid, S., S. Iftikhar, A. Munir and I. Ahmed. 2000. Potato diseases in Pakistan. PARC, Islamabad. pp. 4.

Khurana, S.M.P., I.D. Garg. 1998. Present status of controlling mechanically and non-persistently aphid-transmitted potato viruses. In: Plant Virus Disease Control.
Hadidi A., R.K. Khetarpal and H. Koganezawa. (eds.). APS Press, St. Paul, MN, USA. pp. 593-615

MacGillivary, J.R. 1953. Vegetable production. The Blackistan Company Inc. New York, pp. 354-364.

Mughal, S.M. and S. Khalid, 1985. Viruses Disease in Relation to Potato Production in Pakistan, Pakistan Agriculture Research Council, Islamabad. pp: 154-65.

Mughal, S.M., S. Khalid and Z. Hussain. 1986. Isolation, Identification and prevalence of tobacco viruses in Pakistan. Pak. Tobac. 10: 5-9.

Muhammad, R. 1990. Studies on viral diseases of potato crop in NWFP. M .Sc. (Hons) Thesis, Dept. Pl. Path. NWFP. Agric. Univ. Peshawar.

Petrunak D.M., F.E. Gildow and B.J. Christ. 1991. Incidence and distribution of six viruses infecting potatoes in Pennsylvania. Plant Dis. 75: 644

Rauscher, G.M., C.D. Smart, I. Simko, M. Bonierbale, H. Mayton, A. Greenland and W. E. Fry. 2006. Characterization and mapping of RPi-ber, a novel potato late blight resistance gene from Solanum berthaultii. Theor. Appl. Genet. 112: 674-687.

Rodriguez, A and R.A.C. Jones. 1978. Enanismo amarillo disease of Solanum andigenapotatoes is caused by potato leaf roll virus. Virology. $98: 45-54$.

Zehnder, G. 2010. Overview of Monitoring and Identification Techniques for Insect Pests. Clemson University. extension, Cooperative Extension System, USA. 